Original Research Paper

\title{
Penguatan Konsep Dasar Fisika Dengan Metode Pembelajaran Gasing Pada Siswa dan Guru MA Pondok Pesantren Aikmual Lombok Tengah NTB
}

\author{
Hiden $^{1}$, Lily Maysari Angraini ${ }^{1}$, Marzuki $^{1}$, Susi Rahayu ${ }^{1}$

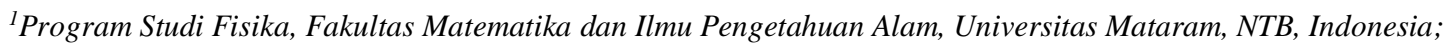

DOI: https://doi.org/10.29303/jpmpi.v3i2.518

Sitasi : Hiden., Angraini, L. M., Marzuki., \& Rahayu, S. (2020). Penguatan Konsep Dasar Fisika Dengan Metode Pembelajaran Gasing Pada Siswa dan Guru MA Pondok Pesantren Aikmual Lombok Tengah NTB. Jurnal Pengabdian Magister Pendidikan IPA, 3(2)

\author{
Article history \\ Received: 30 September 2020 \\ Revised: 14 Oktober 2020 \\ Accepted: 29 Desember 2020 \\ *Corresponding Author: Lily \\ Maysari Angraini, Program \\ Studi Fisika FMIPA, \\ Universitas Mataram, \\ Indonesia; \\ Email: \\ lilyangraini@unram.ac.id
}

\begin{abstract}
For a long period, some students in schools thought that Physics and Mathematics were difficult subjects. These two subjects are a scourge for students in most schools, not only in the NTB area but also in various other regions throughout Indonesia. For this reason, multiple efforts need to be made to overcome these learning difficulties. Learning Physics and Mathematics should emphasize providing direct experience to develop student competencies, directed to "find out" and "do" to help students gain understanding. It will be significantly easier for students if learning Physics and Mathematics invites students to learn to formulate concepts inductively, based on empirical facts, first through the inquiry method. Teachers are faced with the low necessary abilities of students. Not a few teachers have complained about their students' low abilities, especially in understanding the basic concepts of Physics and Mathematics. Many factors influence this, one of which is the input factor (students). Students from different schools have different levels of understanding, both in Physics and Mathematics. It is a fact that, in general, students who graduated from SMP / M.Ts. There are still many basic concepts of Physics and Mathematics which are relatively low. When comparing students who come from city and out of town schools, public and private schools, they have quite significant differences in graduates' ability. This condition also contributes to the low quality of the input. Based on this condition, we hold community service activities to strengthen understanding of the basic concepts of Physics and Mathematics for students as their initial provision for studying other material in more depth. The approach used is an empirical approach with guided inquiry methods. The results obtained are that the learning method of this model is very popular with students and teachers, and with the help of Guided Inquiry-based worksheets, it is straightforward for students to improve their understanding of the basic concepts of physics and mathematics, because the guidance in the LKS is very structured.
\end{abstract}

Keywords: discovery learning, inkuiry, gasing method, fundamental physics concepts. 


\section{Pendahuluan}

$\mathrm{P}$ aradigma belajar fisika itu sulit sudah menjadi momok yang menakutkan untuk siswa. Pembelajaran yang didominasi dengan rumusrumus fisika dan latihan soal yang membuat kening berkerut kerapkali dijadikan sebagai metode pamungkas dalam proses belajar-mengajar fisika. Padahal konsep dasar pengajaran sains yang dititikberatkan pada proses penemuan atau lebih dikenal dengan discovery learning yang telah diusulkan oleh Piaget terbukti berhasil membangun critical thinking siswa dan juga mengubah mindset dari fisika sulit menjadi fisika gasing (gampang, asyik dan menyenangkan) Reif (1995).

Akan tetapi dalam prakteknya, metode pembelajaran ini amat jarang diterapkan. Alasan klasikal yaitu durasi waktu pengajaran akan bertambah, kurangnya atau bahkan tidak tersedianya alat eksperimen, materi yang ajar yang menumpuk dan segera dituntaskan adalah sederet kondisi pembenaran untuk menerapkan metode pembelajaran konvensial yaitu ceramah-contoh soal-tugas[ ].

Hal ini juga terjadi di sekolah mitra kegiatan pengabdian ini. Hasil wawancara team pengabdian dengan kepala sekolah menyimpulkan bahwa pembelajaran fisika yang dilakukan masih berpusat pada guru dengan skema kegiatan penjelasan materi - contoh soal - tugas. Siswa tidak diberikan kesempatan untuk mengeksplorasi pengalaman belajarnya sendiri dan mengkonstruksi critical thinking dalam memecahkan masalah.

Oleh karena itu, dalam kegiatan pengabdian ini, team pengabdian mengadakan kegiatan pembinaan untuk guru dan siswa mitra untuk menguatkan konsep dasar pembelajaran fisika melalui metode fisika gasing (gampang, asyik dan menyenangkan).

Gasing adalah suatu akronim yang dari gampang, asyik dan menyenangkan. Surya Institute (2015) menjelaskan bahwa metode gasing merupakan suatu metode pembelajaran dengan menggunakan cara yang lebih sederhana dan dipadukan dengan pendekatan logika dan meminimalisir penggunaan rumus serta menekankan pada suatu pembelajaran berupa kegiatan eksplorasi nyata (konkret) dari materimateri yang disesuaikan dengan kurikulum sekolah.

Dalam lima tahun terakhir ini, teknik pembelajaran gasing pada fisika di klaim berhasil. Beberapa penelitian sudah membuktikan itu diantaranya Irawan (2015) mengimplementasikan metode gasing untuk meningkatkan hasil belajar pada materi mekanik zat (Hukum Hooke) untuk siswa kelas X di SMK Negeri 2 Pati. Nurfathonah (2017) mengaplikasikan metode gasing untuk meningkatkan hasil belajar siswa kelas $\mathrm{X}$ di Polongbangkeng Utara. Astwan et al (2013) berhasil meningkatkan kemampuan aktivitas dan kemampuan memecahkan masalah pada siswa melalui pembelajaran teknik gasing. Purwasari (2020) melakukan kajian pendekatan saintifik dengan metode gasing pada pembelajaran fisika.

Berdasarkan hasil penelitian yang dipaparkan diatas, dapat disimpulkan bahwa metode gasing efektif untuk mengubah paradigma fisika sulit menjadi fisika menyenangkan. Dengan demikian, pembelajaran fisika tidak monoton membahas buku teks dan mengerjakan soal, namun akan lebih bervariasi dan lebih menarik. Oleh karena itu, team pengabdian akan menerapkan metode ini pada mitra.

\section{Metode}

Kegiatan ini dititikberatkan pada konsep pembelajaran sains yang dikemukakan oleh Piaget yaitu metode inkuiri dan discovery learning. Selain itu, pembelajaran dilengkapi dengan alat eksperimen untuk menegaskan bahwa pembelajaran fisika itu asyik dan menyenangkan. Adapun langkah-langkah kegiatan sebagai berikut :

\section{Tahapan Penyusunan Instrumen Kegiatan}

Pada tahapan ini, team menganalisis karakteristik materi ajar yang akan dikuatkan konsepnya. Hal ini sangat perlu dilakukan untuk bisa menentukan metode pembelajaran yang tepat. Selain itu, mengetahui karakteristik materi ajar akan memudahkan team untuk menyusun rencana pembelajaran serta alat eksperimen penunjang pembelajaran.

Selain analisis karakteristik bahan ajar, pada tahapan ini, team juga menganalisis karakteristik siswa dan guru yang merupakan sasaran kegiatan pengabdian. Need assesment awal ini bertujuan untuk memetakan kemampuan awal siswa dan guru pada materi tersebut. 


\section{Tahapan Pelaksanaan Kegiatan}

Siswa dan guru dikelompokkan dalam kelompok-kelompok kecil yang beranggotakan $2-3$ orang dalam setiap kelompok. Anggota kelompok dipilih acak, tidak didasarkan pada tingkat kemampuan kognitif. Masing-masing kelompok diberikan lembar kerja siswa dan guru yang sudah disusun sesuai dengan langkah-langkah metode pembelajaran inkuiri dan discovery learning.

Untuk menyelesaikan lembar kerja tersebut, juga disedikan alat eksperimen sederhana sesuai dengan langkah discovery learning.

\section{Tahap Evaluasi}

Evaluasi dilakukan dengan cara mengoreksi lembar kerja siswa dan guru. Observasi cara menggunakan alat eksperimen sederhana yang telah disediakan serta mengevaluasi cara penyajian data hasil eksperimen.

\section{Hasil dan Pembahasan}

Pada kegiatan ini, konsep dasar yang dikuatkan pemahamannya adalah materi gerak parabola. Miskonsepsi yang sering terjadi pada materi ini adalah (1) konsep trigonometri dalam menentukan komponen-komponen vektor kecepatan awal dalam arah sumbu $\mathrm{X}$ dan sumbu Y. (2) Menggambarkan grafik energi sebagai fungsi posisi. (3) Miskonsepsi kecepatan akhir sama dengan minus kecepatan awalnya. (4) Kesalahan konsep bahwa semua energi kinetik awal akan berubah seluruhnya menjadi energi potensial pada titik puncak. (5) kesulitan menginterpretasikan grafik dan (6) Berdasarkan grafik yang diperoleh, siswa belum mampu membaca pada titik dimanakah energi kinetik dan potensial memiliki nilai yang sama.

Miskonsepsi ini diluruskan dengan memberikan penguatan sebagai berikut :

Konsep yang diberikan adalah mengenai konsep gradient garis singgung yang tidak lain merupakan konsep diperensial. Pertama kali siswa diminta untuk membuat fungsi $y$ atas $x$ $(y=f(x))$ yang mana tadinya keduanya ( $x$ dan y) sama-sama merupakan fungsi terhadap waktu, yaitu

$$
x=v_{x_{0}} \cdot t, \text { dan } y=v_{y_{0}} \cdot t-\frac{1}{2} g t^{2} .
$$

Pada awalnya tadinya hal ini tidak mudah mereka lakukan. Akan tetapi dengan panduan yang diberikan pada LKS, akhirnya mereka bisa dapatkan dengan mudah, dan mendapatkan hasil sebagaimana yang diharapkan yaitu

$$
y=-\frac{g}{2 v_{x_{0}}{ }^{2}} x^{2}+\frac{v_{y_{0}}}{v_{x_{0}}} x .
$$

Langkah selanjutnya siswa diminta untuk mendiferensialkan fungsi y yang didapatkan ini terhadap $x$, yaitu mencari $\frac{d y}{d x}$ dan diinformasikan bahwa gradien pada titik puncak grafik adalah nol, sehingga akan diperoleh ungkapan $x$ pada titik puncak grafik yaitu $x=\frac{v_{x_{0}{ }^{0}} v_{y_{0}}}{g}$. Lalu dengan mensubstitusi nilai $x$ ini pada persamaan gerak

$$
y=-\frac{g}{2 v_{x_{0}}{ }^{2}} x^{2}+\frac{v_{y_{0}}}{v_{x_{0}}} x,
$$

Maka di peroleh

$$
y=\frac{v_{y_{0}}^{2}}{2 g} .
$$

Materi pendalaman selanjutnya adalah tentang aljabar, yaitu mencari sumbu simetri dari persamaan parabola $y=a x^{2}+b x+c$, yang ditentukan oleh: $x=-\frac{b}{2 a}$. Siswa diminta untuk mengidentifikasi koefisien-koefisien $a, b$, dan $c$ melalui persamaan gerak parabola yang sudah diketahui,

$$
y=-\frac{g}{2 v_{x_{0}}{ }^{2}} x^{2}+\frac{v_{y_{0}}}{v_{x_{0}}} x,
$$

sehingga diharapkan nantinya ditemukan koefisien

$$
a=-\frac{g}{2 v_{x_{0}}{ }^{2}}, b=\frac{v_{y_{0}}}{v_{x_{0}}} \text { dan } c=0
$$

sehingga diperoleh:

$$
x=\frac{v_{x_{0}}, v_{y 0}}{g} .
$$

Sedangkan nilai $y_{\text {maks }}$ diperoleh dari

$$
y_{\text {maks }}=-\frac{D}{4 a},
$$

dimana diskriminan

$$
D=b^{2}-4 a c \text {. }
$$

Hasil yang diharapkan adalah

$$
y_{\text {maks }}=\frac{v_{y_{0}}^{2}}{2 g} \text {. }
$$


Kemudian, dari

$$
y=-\frac{g}{2 v_{x_{0}}{ }^{2}} x^{2}+\frac{v_{y_{0}}}{v_{x_{0}}} x
$$

apabila diambil nilai $y=0$, didapat

$$
x=2 \frac{v_{x_{0}, v_{y_{0}}}}{g} \text {. }
$$

Ini tidak lain adalah koordinat titik terjauh dari gerak parabola.

Berikut foto kegiatan penguatan konsep dasar pada materi gerak parabola

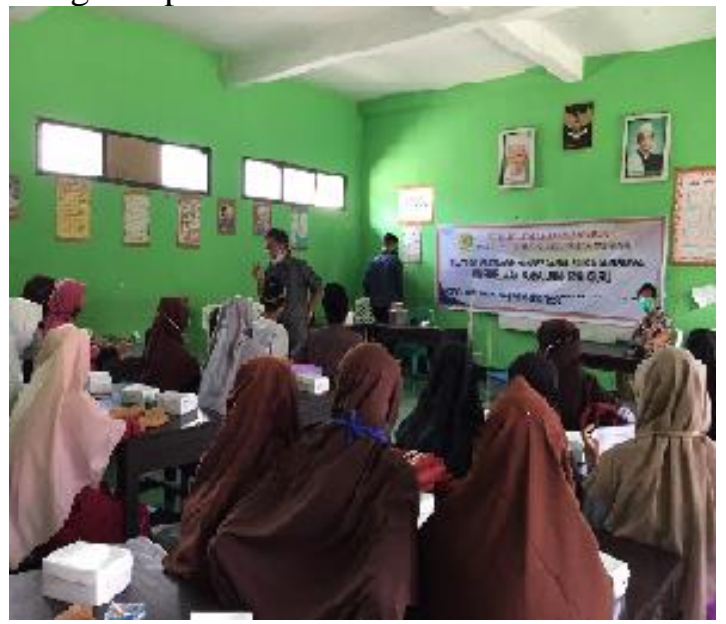

Gambar 1. Penguatan Konsep gerak parabola

\section{Kegiatan Eksperimen dengan Alat Sederhana}

Untuk menunjang pemahaman, lembar kerja

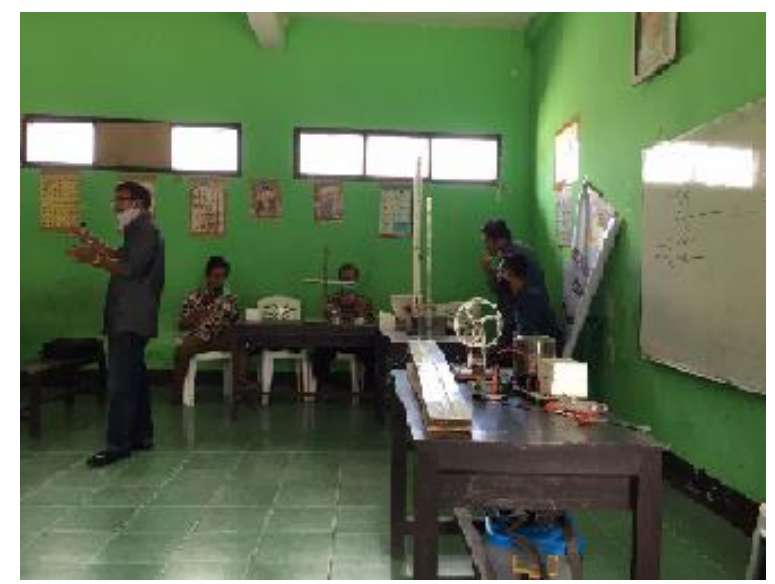

dilengkapi dengan alat peraga yaitu

Gambar 2. Alat Peraga Gerak parabola

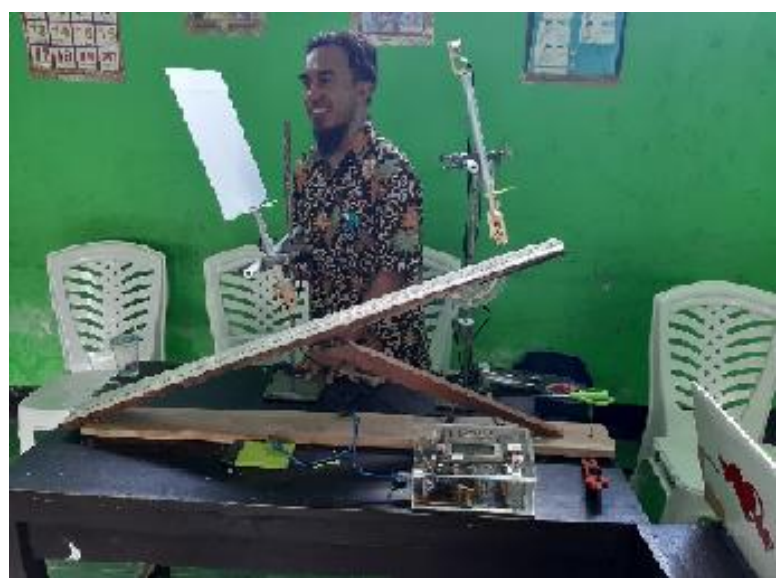

Gambar 3. Demonstrasi Pengambilan data

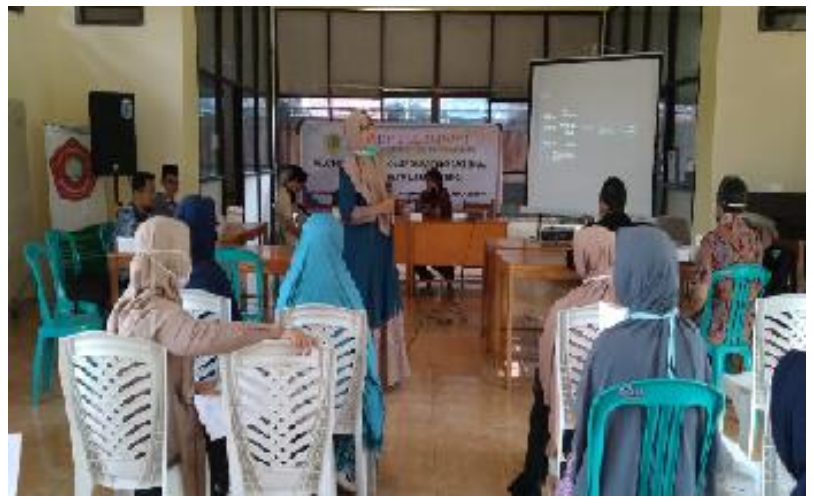

Gambar 4. Penguatan Konsep Dasar Untuk Guru

\section{Kesimpulan}

Rendahnya pemahaman konsep siswa baik pada bidang fisika maupun matematika dapat diminimalisasi dengan berbagai metode, antara lain dengan metode pembelajaran berbasis inkuiri terbimbing, yaitu berupa tuntunan yang dikemas dalam bentuk LKS yang menuntun siswa untuk menemukan sendiri konsep yang diinginkan.

Metode inkuiri dan discovery learning yang dikemas dalam teknik pembelajaran gasing (gampang, asyik dan menyenangkan) mampu mengubah paradigma pembelajaran fisika sulit. Selain itu, dari hasil evaluasi yang dilakukan dan observasi hasil melalui wawancara setelah kegiatan berakhir, siswa dan guru berpendapat bahwa pembelajaran fisika yang dikemas dengan basis penemuan dan dilengkapi alat eksperimen sederhana mampu meningkatkan motivasi belajar dan 
mengajar siswa dan guru di MA Pondok Pesantren Aikmual Lombok Tengah NTB.

\section{Saran}

Secara keseluruhan, kegiatan pendampingan semacam ini menurut pimpinan pondok pesantren, para guru dan juga santri, dirasakan manfaatnya sangat besar terutama dalam meningkatkan pemahaman konsep-konsep dasar fisika dan matematika khususnya bagi para santri di pondok pesantren. Pimpinan pondok pesantren mengharapkan kegiatan semacam ini memiliki keberlanjutan pada masa-masa yang akan datang. Diharapkan juga kegiatan pemantapan ini tidak saja dilakukan pada bidang fisika dan matematika tetapi juga pada bidang lainnya, demi tercapainya kualitas pendidikan yang lebih baik, utamanya di pondok pesantren mitra dan Nusa Tenggara Barat umumnya. Kepada pihak LPPM Unram, hendaknya mengalokasikan dana yang lebih besar untuk kegiatan semacam ini, agar dapat menjangkau masyarakat yang lebih luas, utamanya masyarakat sekolah.

\section{Ucapan Terima Kasih}

Kegiatan Pengbadian ini didanai oleh Universita Mataram dalam skema pengabdian PNBP 2020. Terimakasih juga kami ucapkan kepada Bapak kepala sekolah MA Pondok Pesantren Aikmual Lombok Tengah NTB yang sudah bersedia menjadi mitra kegiatan ini.

\section{Daftar Pustaka}

I Gede Astawan, I Wayan Mustika (2013). Meningkatkan Aktivitas dan Kemampuan Memecahkan Masalah melalui Pembelajaran Kuantum Teknik Fisika Gasing

Nurfathonah (2017). Implementasi Metode Pembelajaran GASING (Gampang, Asyik dan Menyenangkan) Terhadap Hasil Belajar Fisika Peserta Didik Kelas X SMA Negeri 3 Polongbangkeng Utara. Jurnal Pendidikan Fisika Universitas Muhammadiyah Makasar.

Nuryahman Wahyu Irawan (2015). Metode Gasing Dengan Eksperimen Untuk Meningkatan Hasil Belajar Fisika Konsep Mekanik Zat
(Hukum Hooke) Pada Peserta Didik Kelas $X$ Multimedia Smk Negeri 2 Pati Semester Genap Tahun Ajaran 2014/2015. Proceeding Seminar Nasional Pendidikan Sains. Magister Pendidikan Sains dan Doktor Pendidikan IPA FKIP UNS

Reif, F. (1995). "Understanding and Teaching Important Scientific Thought Processes", American Journal of Physics. 63(1)

Yessi Purwari (2020). Pendekatan Saintifik dengan Metode Gasing pada Pembelajaran Fisika. Jurnal Penelitian Guru Indonesia. 